\title{
Information technologies in teaching humanitarian disciplines
}

\section{Tecnologías de la información en la enseñanza de disciplinas humanitarias}

\author{
Irina M. Morozova \\ Penza State Technological University, Penza, Russia \\ ORCID: https://orcid.org/0000-0003-2249-8332 \\ Valery N. Lyusev \\ Penza State Technological University, Penza, Russia \\ ORCID: https://orcid.org/0000-0001-6277-0017
}

\section{Marina N. Gladkova}

Tyumen Higher Military Engineering Command School. Marshal of the engineering troops AI. Proshlyakov of the Ministry of Defense of the Russian Federation, Tyumen, Russian Federation

ORCID: https://orcid.org/000-0001-9122-5712

\section{Elena V. Smirnova}

Togliatti State University, Togliatti, Russia

ORCID: https://orcid.org/0000-0002-3658-2095

\section{Julia A. Kulagina}

Penza State Technological University, Penza, Russia

ORCID: https://orcid.org/0000-0002-8892-0367

*Correspondence

Email: ivannovadremova29@gmail.com
Cite as:
Morozova, I., Lyusev, V., Gladkova, M., Smirnova, E.,
$\begin{aligned} & \text { Kulagina, J. (2021). Information technologies in } \\ & \text { teaching humanitarian disciplines. Propósitos }\end{aligned}$ y
$\begin{aligned} & \text { Representaciones, } 9 \\ & \text { http://dx.doi.org/10.20511/pyr2021.v9nSPE1.817 }\end{aligned}$ 


\section{Summary}

The use of information technology in teaching humanitarian disciplines contributes to the formation of highly qualified, competitive specialists who can adapt to rapidly changing conditions, possessing a high level of development of critical and creative thinking, ready for professional self-development and self-improvement, for the implementation of reflection, capable of setting goals and systematically achieving them. The work actualizes the importance of information technology in the training of highly qualified competitive specialists capable of implementing professional activities at a high level. The purpose of the article is to analyze the experience of implementing information technologies in teaching humanitarian disciplines. Smart boards, multimedia installations, document cameras, electronic textbooks, electronic educational platforms and others were used as information technologies used in the teaching of the humanities. The study made it possible to reveal the influence of information technologies on the level of formation of students' competencies.

Keywords: Messenger - communication - integration - service - application.

\section{Resumen}

El uso de la tecnología de la información en la enseñanza de disciplinas humanitarias contribuye a la formación de especialistas altamente calificados y competitivos que pueden adaptarse a condiciones rápidamente cambiantes, poseer un alto nivel de desarrollo del pensamiento crítico y creativo, listos para el autodesarrollo y la superación profesional. para la implementación de la reflexión, capaz de fijar metas y alcanzarlas de manera sistemática. El trabajo actualiza la importancia de la tecnología de la información en la formación de especialistas competitivos altamente calificados capaces de implementar actividades profesionales de alto nivel. El propósito del artículo es analizar la experiencia de implementar tecnologías de la información en la enseñanza de disciplinas humanitarias. Se utilizaron pizarrones inteligentes, instalaciones multimedia, cámaras de documentos, libros de texto electrónicos, plataformas educativas electrónicas y otros como tecnologías de la información utilizadas en la enseñanza de las humanidades. El estudio permitió revelar la influencia de las tecnologías de la información en el nivel de formación de las competencias de los estudiantes.

Palabras clave: Messenger - comunicación - integración - servicio - aplicación.

\section{Introducción}

The development and implementation of new technological solutions based on information technologies in various spheres of social life necessitate their use in training students of higher educational institutions. (Aleksieienko-Lemovska, 2019). Teaching humanitarian disciplines in vocational education play a significant role in shaping the competence of a future graduate (Andriushchenko, 2018). The use of information technologies in teaching humanitarian disciplines is becoming more and more popular, allowing us to expand the opportunities for training students (Andrienko, 2019).

The use of information technologies in the educational process is widely discussed in modern science and practice (Bakharev, 2019). This issue was investigated by O.F. Bryksina, E.N. Zaitseva, I.G. Zakharova, L.I. Gorbunova and others. However, today there are still a number of controversial issues that need to be resolved. The topic of the use of information technology in the teaching of humanities in vocational education requires a more detailed study.

The humanities make a significant contribution to the development of the student's personality, his culture. Humanities contribute to the formation of a competitive specialist who possesses not only professional competencies but also intellectual, cultural, spiritual potential. 
Humanities are distinguished by their variability, the ability to obtain many options for solving one problem. In the teaching of the humanities, a large number of different points of view, which are equally scientific in nature, are of high importance (Vaganova et al., 2019c). Teaching such disciplines has specific opportunities for the development of students' creative thinking. The curriculum provides for the study of a certain number of humanitarian disciplines, including philosophy, sociology, cultural studies. In the first year of study, these are some of the fundamental disciplines that contribute to the development of a scientific worldview (Pinkovetskaia et al, 2020). We analyze the experience of implementing information technologies by their example.

We consider information technologies as methods of searching, storing, processing and presenting information, methods of working with information, implemented using various technical means. These funds may include:

- smartboards;

- eBooks;

- visualizers (document cameras);

- multimedia projectors;

- video cameras (Vaganova et al., 2019);

- audio equipment;

- video equipment;

- multipoint video conferencing;

- e-learning programs;

- electronic educational platforms (Denisova et al., 2019).

The implementation of information technology in a higher educational institution contributes to:

- effective use of information and electronic resources at the university (Filchenkova, 2019);

- active dissemination of digital technologies in the teaching process (Grigoriev et al., 2019).

Modern information technologies have a significant impact on the components of the educational process (Halatsyn \& Feshchuk, 2019). And this has a positive effect on the availability of training and allows you to improve the quality of training due to:

- conducting classes and consultations remotely (Ilyashenko et al., 2019);

- the use of computer graphics to improve the clarity of information (Koshechko, 2018);

- increasing the intensity of independent work (Kamenez et al., 2019);

- ensuring fast information retrieval (Klinkov, 2018).

- implementation of timely control of learning outcomes by obtaining automatic results (Pliushch, 2018).

The effectiveness of the use of information technology in the teaching of humanitarian disciplines depends on many factors, including:

- prediction by the teacher of the possible consequences of the impact of information technology on the nature of thinking and behavior of students (Myalkina, 2019);

- choice of ways to combine information technology with traditional teaching aids (Oros, 2018);

- creating appropriate learning conditions (taking into account the individual characteristics of students, organizing individual consultations and others) (Pichugina \& Bondarchuk, 2019a).

In the process of preparing for classes, students can use audio and video tools (Pichugina \& Zhilyakova, 2019b). Their advantage is that students can both listen to the material and view (Pisarenko, 2019). In addition, using special programs, students in the process of preparing for 
classes (to participate in games and projects) can create video clips on their own (Smirnova et al., 2019).

Information technologies in teaching humanitarian disciplines contribute to the organization of interaction between students and teachers, create conditions for automated control, the ability to use various information, act as a way to improve the effectiveness of training (Vaskovskaya et al., 2018).

In the article, we analyze the experience of implementing information technologies in a higher educational institution using the example of humanitarian disciplines.

\section{Methods}

The study was conducted in 2018 and 2019 among 68 first-year students of a higher educational institution.

In the process of studying sociology, philosophy and cultural studies, modern information technologies were introduced, which made it possible to make it more intense, visual, and accessible.

The formation of competence was carried out at lectures, practical (seminar) classes, in the process of performing independent work.

The formation of the competence "the ability to use the foundations of philosophical and socio-humanitarian knowledge to form a scientific worldview" was checked according to specially selected criteria specified in the work, before and after the implementation of the technologies under consideration (Arbeláez-Campillo, \& Rojas-Bahamon, 2020).

\section{Results and discussion}

Smartboards, multimedia installations, document cameras, electronic textbooks, electronic educational platforms and others were used as information technologies used in the teaching of humanities (Abramova et al., 2018).

When studying such humanitarian disciplines, such as sociology, cultural studies, philosophy, students use various information tools that expand the opportunities for studying lecture material and preparing for practical and seminars (Bulaeva et al., 2018).

In the process of studying the lecture material, students were offered electronic textbooks that facilitate independent operational processing of knowledge. Compared to a traditional book, an electronic book clearly and presents information, provides a simplified search for information, is supplemented by electronic notebooks, entries in which can be corrected by both the student and the teacher at any time. To repeat lectures, students are given access to electronic educational platforms, where an appropriate electronic course has been developed for each specific discipline.

A document camera was used as a computer tool that implements the fundamental principle of teaching, which is necessary when showing images from paper media on a large screen. She performs the following functions in teaching the humanities:

- demonstrates stationary images, allows you to enlarge them (pages, full images or their elements, text elements);

- demonstrates the teacher's actions in real time (Vaganova et al., 2019).

The development and consolidation of the skills of using the foundations of philosophical knowledge for the formation of an ideological position presuppose not only mastering the theory, 
but also obtaining practical work skills. For this, discussions are held, round tables, where some problematic issues are discussed, games, design work is carried out.

When students participated in the discussion, the quotes, models, and positions of opponents were demonstrated on the screen.

To organize interaction in the process of preparing the project, various messengers were used, which allowed students to quickly discuss emerging issues among themselves.

Consultations with the teacher were carried out remotely using the electronic educational platform Moodle. Forums and chats were created where students discussed general issues. The instructor supervised and guided the process.

The protection of student projects was carried out using multimedia projectors. During the presentations, the students demonstrated the results of their work on a large screen (an interactive whiteboard was also used as a screen). Students from other universities acted as opponents. The interaction was carried out using the Webinar tool on the Moodle platform.

In the course of the training, videoconferencing was organized, where the exchange of experience among students and teachers of different universities was carried out.

We checked the formation of the competence "the ability to use the foundations of philosophical and socio-humanitarian knowledge to form a scientific worldview", which is formed among undergraduate students in the process of studying "Philosophy", "Sociology", "Culturology". To do this, we have identified high, medium and low levels in accordance with which the corresponding criteria were correlated.

Figure 1 shows the levels of formation of the general competence "the ability to use the foundations of philosophical and socio-humanitarian knowledge for the formation of a scientific worldview."

Table 1.

Levels of formation of general cultural competence of students.

\begin{tabular}{|l|l|}
\hline Level & Characteristic \\
\hline High & $\begin{array}{l}\text { Has a good knowledge of basic philosophical and socio-humanitarian categories and } \\
\text { concepts, independently applies philosophical and socio-humanitarian categories and } \\
\text { concepts to study other disciplines of the curriculum, freely uses the foundations of } \\
\text { philosophical and socio-humanitarian knowledge to form a scientific worldview }\end{array}$ \\
\hline Middle & $\begin{array}{l}\text { He is familiar with basic philosophical and socio-humanitarian categories and } \\
\text { concepts can apply philosophical and socio-humanitarian categories and concepts to } \\
\text { study other disciplines of the curriculum, uses the foundations of philosophical and } \\
\text { socio-humanitarian knowledge to form a scientific worldview }\end{array}$ \\
\hline Low & $\begin{array}{l}\text { Does not possess knowledge of basic philosophical and socio-humanitarian categories } \\
\text { and concepts, does not apply philosophical and socio-humanitarian categories and } \\
\text { concepts to study other disciplines of the curriculum is not able to use the foundations } \\
\text { of philosophical and socio-humanitarian knowledge to form a scientific worldview }\end{array}$ \\
\hline
\end{tabular}

Figure 1 shows the formation of the competence "the ability to use the foundations of philosophical and socio-humanitarian knowledge to form a scientific worldview" before and after the introduction of information technology in the preparation of students studying philosophy, sociology, and cultural studies in the 1st year. 


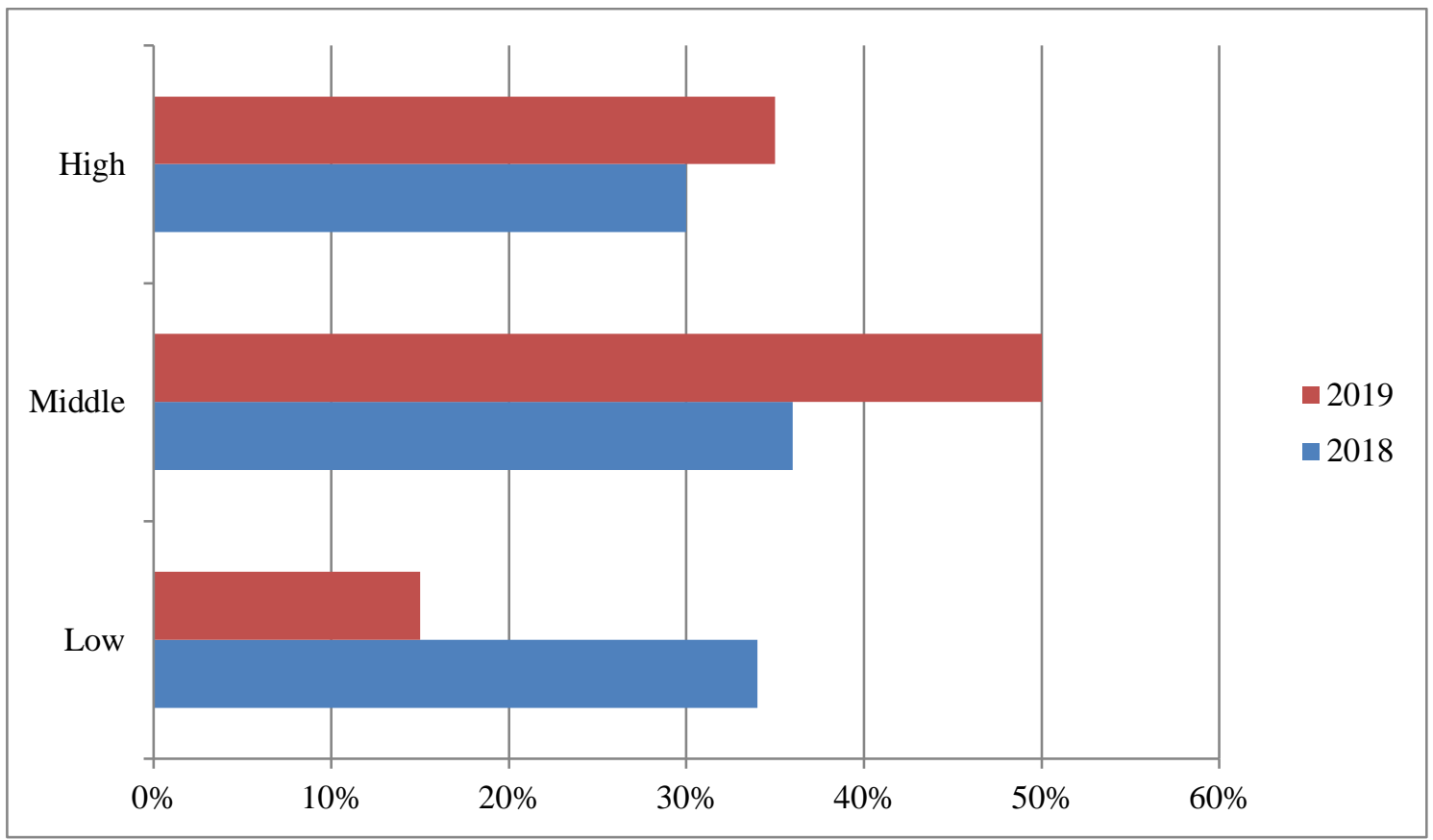

Figure 1. Comparative characteristics of learning outcomes before and after the introduction of information technologies in student training.

A high level of competence formation in 2019 compared to 2018 began to be possessed by $35 \%$ of students, an average $-50 \%$ of students.

\section{Conclusion}

The use of information technology in teaching humanitarian disciplines contributes to the formation of highly qualified, competitive specialists who can adapt to rapidly changing conditions, possessing a high level of development of critical and creative thinking, ready for professional self-development and self-improvement, for the implementation of reflection, capable of setting goals and systematically achieving them. The study revealed the functional significance of information technologies in teaching humanitarian disciplines, their use in the process of forming competence.

Conflict of interests: The authors declare that they have no conflicts of interest.

Authors' contribution: The authors have participated in the research process, in the writing of the work and in the analysis of the documents.

\section{References}

Abramova, N.S., Vaganova, O.I., \& Kutepova, L.I. (2018). Development of educational and methodological support in the context of the implementation of content and communication technologies. Baltic Humanitarian Journal, 7, 2 (23), 181-184.

Aleksieienko-Lemovska, L.V. (2019). The activity approach as a basis for preschool teachers' methodological activities. Humanitarian Balkan Research, 3, 4(6), 10-14.

Andrienko, O.A. (2019). Network educational technologies and their use when working with students. Humanitarian Balkan Research, 1(3), (2019): 5-7. 
Andriushchenko, T. K., (2018). Personal aspects of pedagogue's innovative culture, Scientific Vector of the Balkans, 1, 13-16.

Arbeláez-Campillo, D.F., \& Rojas-Bahamon, M.J (2020). "Pandemics in globalization times". Amazonia Investiga, $9(27), \quad 3-4$. https://amazoniainvestiga.info/index.php/amazonia/article/view/1189

Bakharev, N. P., (2019). Creativity - a prerequisite for the formation of professional competences in specialists of technical direction of training. Scientific Vector of the Balkans, 3, 4 (6), $17-21$.

Bulaeva, M.N., Vaganova, O.I., \& Gladkova M.N. (2018). Activity technologies in a professional educational institution. Baltic Humanitarian Journal, 7, no. 3 (24), 167-170.

Denisova, O.P., Smirnova, Z.V., Vaganova, O.I., Gladkova, M.N., \& Tsarapkina, J.M. (2019). Development of partnerships in additional education. International Journal of Innovative Technology and Exploring Engineering, 8 (8), 639-643.

Filchenkova, I.F. (2019). Educational management of innovative activity of teachers as an object of pedagogical research. Vestnik of Minin University, 7 (4), 3.

Grigoriev S. G., Shabunina V. A., Tsarapkina Ju. M., \& Dunaeva N. V. (2019). Electronic library system as a means of self-development of students of digital generation $\mathrm{Z}$ (on the example of studying the course "Basics of the counselor activity"), Scientific and technical libraries, 7, 78-99.

Halatsyn, K.A., \& Feshchuk, A.M. (2019). Diagnosing motivational-and-valuable component of the communicative culture of students in higher technical educational institutions, Balkan Scientific Review, 3, 2 (4), 17-20.

Ilyashenko, L. K., Smirnova, Zh. V., Vaganova, O. I. Chelnokova, E. A., \& Kaznacheeva, S.N. (2019). Methods of Conducting Practical Training on the Subject "Power Sources for Welding", International Journal of Mechanical Engineering and Technology, 10 (02), 908-917.

Kamenez, N.V., Smirnova, Zh. V., Vaganova, O. I., Bystrova, N.V., \& Tsarapkina, J.M., (2019). Development of Instructing Techniques in Professional Training, International Journal of Mechanical Engineering and Technology, 10(02), 899-907.

Klinkov, G.T. (2018). The specificity of manifestation of pedagogical communication as a special construct. Scientific Vector of the Balkans, 1, 51-52.

Koshechko, N.V. (2018). Innovations from educational discipline "Pedagogical conflictology" in professional preparation of students. Scientific Vector of the Balkans, 1, 59-63.

Myalkina, E.V. (2019). Diagnostics of the education quality in the higher educational institution. Vestnik of Minin University, 7, (3), 4.

Oros, I.I. (2018) The role of international connections in the development of the adult education system. Humanitarian Balkan Research, 1, 57-59.

Pichugina, G. A., \& Zhilyakova, D. A. (2019b). Structuring the organization of the process of creativity. Scientific Vector of the Balkans, 3, 3 (5), 55-58. 
Pichugina, G.A., \& Bondarchuk (2019a). A.I. Structure of the training case in the organization of the educational process. Humanitarian Balkan Research, 2(4), 5-7.

Pinkovetskaia, I.S, Arbeláez-Campillo, D.F., Rojas-Bahamón, M.J., \& Veas Iniesta. D. (2020). "Motivation of new entrepreneurs in modern economies" Amazonia Investiga, 9(29), 368-373. https://amazoniainvestiga.info/index.php/amazonia/article/view/1403

Pisarenko, D. A. (2019). Evaluation of extracurricular activities of university students with a competency-based approach, Scientific Vector of the Balkans, 3, 3 (5), 37-40.

Pliushch, V.M. (2018). Independent work of students as a factor of improving education quality. Balkan Scientific Review, 1, 69-71.

Smirnova, Z.V., Vaganova, O.I., Loshkareva, D.A., Konyaeva, E.A., \& Gladkova, M.N. (2019). Practice-oriented approach implementation in vocational education, IOP Conference Series: Materials Science and Engineering, 1, 483.

Vaganova, O.I., Ilyashenko, L.I., Smirnova, Zh.V., Bystrova, N.V., \& Kaznacheeva, S.N. (2019a) Students' creative abilities development in higher educational institution. Amazonia $\begin{array}{llll}\text { Investiga, } & 8 & \text { (22), }\end{array}$ https://www.amazoniainvestiga.info/index.php/amazonia/article/view/822

Vaganova, O.I., Rudenko, I.V., Markova, S.M., Smirnova, Zh.V., \& Kutepov, M.M. (2019b). The use of educational video materials in educational process of a higher educational $\begin{array}{lllll}\text { institution. Amazonia Investiga, } & 8 & \text { (22), } & \text { 216-222. }\end{array}$ https://www.amazoniainvestiga.info/index.php/amazonia/article/view/308

Vaganova, O.I., Sirotyk, S.D., Popkova, A.A., Smirnova, Z.V., Bulaeva, M.N. (2019c). Additional education in higher professional educational institution. Amazonia Investiga, 8 (22), 305 - 310. https://www.amazoniainvestiga.info/index.php/amazonia/article/view/448

Vaskovskaya, G.A. (2018). Features of implementation of pedagogical technologies of profile training. Balkan Scientific Review, 1, 76-79. 